\title{
Artículo Especial: Obras maestras del arte universal y la medicina: El retrato de Ambroise Vollard por Pablo Picasso (1881-1973) \\ Universal art masterpieces and medicine: "The Ambroise Vollard portrait" by Pablo Picasso (1881-1973)
}

Carlos G. Musso

"frente al espejo gigante de la pared, vi durante un pequeñísimo momento, al Harry que yo conocía ... pero apenas lo hube reconocido, se desplomó segregándose de él una segunda figura, una tercera, una décima, una vigésima, y todo el enorme espejo se llenó por todas partes de Harrys y de trozos de Harry, de numerosos Harrys, a cada uno de los cuales solo vi y reconocí un momento brevísimo. Algunos de estos Harrys eran tan viejos como yo; algunos, mas viejos; otros, completamente jóvenes, mozalbetes, muchachos, colegiales, niños ...

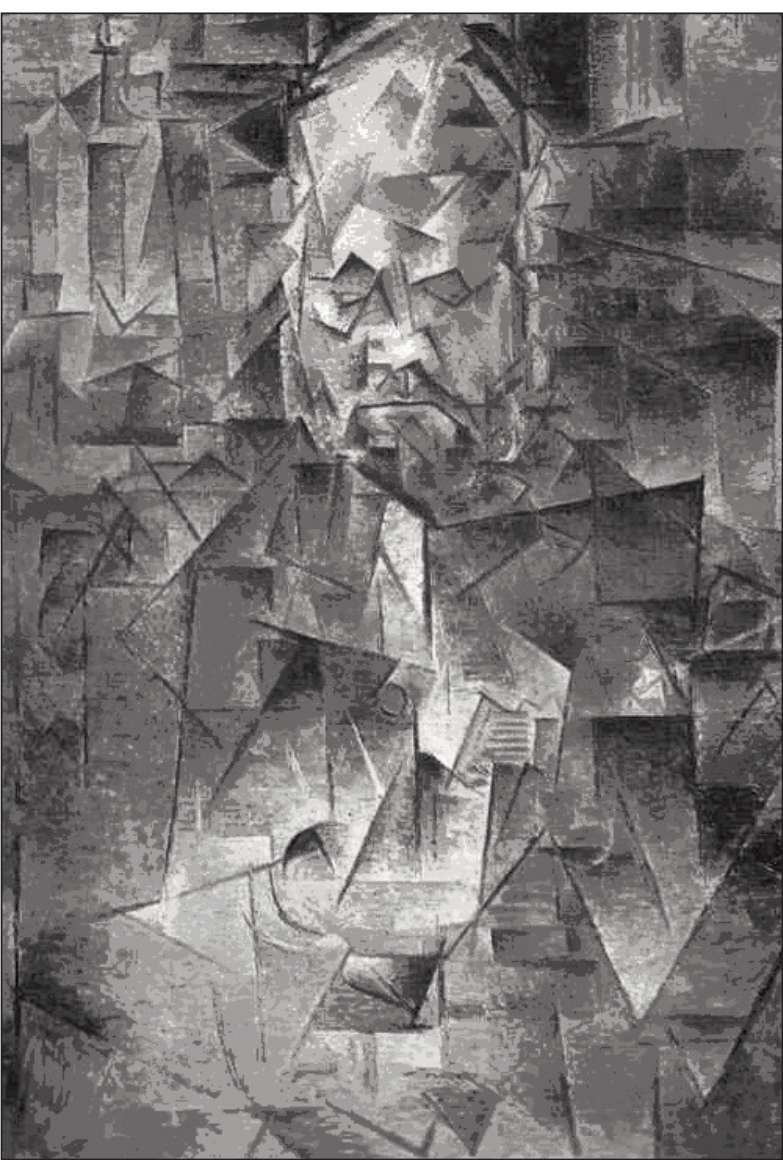

Análisis de la obra

En esta pintura, Pablo Picasso muestra a su amigo y marchante Ambroise Vollard conformado por múltiples y caleidoscópicas perspectivas. Se trata de una obra típica del cubismo hermético, en la que el autor alude claramente a las múlti- ples y variadas facetas que constituyen la pretendida "personalidad" que todo sujeto cree poseer, y que en realidad no es más que una mera fachada de su vida de relación. Picasso, con la perspicaz mirada del genio, vislumbra a los múltiples "Ambroises" que sueñan y palpitan bajo su artificiosa máscara social.

\section{El mito de la personalidad}

El hombre cree erróneamente que por tener un solo cuerpo, necesariamente posee una única personalidad, cuando en realidad porta una miríada de ellas. Cada persona es un caprichoso haz de yoes, algunos de los cuales están en continuo desarrollo, mientras que otros se encuentran adormilados en una etapa embrionaria. No obstante, todos los tipos de personalidades moran, en algún grado y magnitud, en cada ser humano.

Tal vez el ejemplo más claro de este concepto nos lo brinda la mismísima palabra "persona" (del latín persona, y éste del etrusco phersu) la cual remite a la máscara (artificio) que usaban los actores griegos en la Antigüedad, y que es la misma razón por la cual la palabra francesa personne significa "nadie".

La adquisición de este concepto permite comprender que la buena o mala relación que puedan tener las personas se origina en la adecuada o inadecuada correspondencia que puedan tener sus respectivas combinaciones de personalidades, de modo que tan solo un sutil giro del "caleidoscopio personal" puede conducir al consenso o al desencuentro.

Este concepto, aplicado al campo médico asistencial, brinda al terapeuta la oportunidad de abordar exitosamente las características personales de cada uno de sus pacientes, adaptando su propia trama de personalidades, a la propia del enfermo, a fin de lograr una armónica relación, que sirva de marco operativo al acto terapéutico.

\section{Conclusión}

El retrato de Ambroise Vollard de Pablo Picasso, brinda la oportunidad de reflexionar acerca de la naturaleza heterogénea de la personalidad humana, así como de sus implicancias en la tarea asistencial.

\section{Bibliografía recomendada}

Hesse H. El lobo estepario. Buenos Aires. PUL. 2007

Ferrater Mora J. Diccionario de Filosofía . Buenos Aires. Sudamericana. 2004

Corominas J. Breve diccionario etimológico de la lengua castellana. Gredos. 1973

Diccionario Universal Francés - Español. Berlin. Lagenscheidt. 1960

Picasso. En Ricart J (Ed). Grandes maestros de la pintura. Barcelona. Editorial Sol 90. 2007

Allen W. Zelig. (film) 1983 